\title{
PENGARUH OLAHRAGA JALAN SANTAI TERHADAP KADARGLUKOSA DARAH PADA PASIEN DIABETES MELITUS
}

\author{
Arkan Adi Widiya1 $^{1}$, Safari Wahyu Jatmiko', Sigit Widyatmoko², \\ 1. Fakultas Kedokteran Universitas Muhammadiyah Surakarta \\ 2. Rumah Sakit Umum Daerah Simo Boyolali \\ Email: Safari.wahyu@ums.ac.id
}

\begin{abstract}
ABSTRAK
Diabetes Melitus (DM) merupakan penyakit kronis yang terjadi karena pankreas tidak dapat menghasilkan cukup insulin atau tubuh tidak dapat secara efektif menggunakan insulin yang dihasilkan oleh pankreas. Terdapat 4 cara dalam mengontrol kadar glukosa darah yaitu; terapi farmakologi, terapi nutrisi, edukasi cara manajemen diabetes mandiri, dan aktifitas fisik. Berjalan kaki adalah cara yang paling sering ditunjukan sebagai modalitas aktifitas fisik untuk meningkatkan kesehatan. Penelitian ini bertujuan mengetahui pengaruh olahraga jalan satai terhadap kadar glukosa darah pada pasien diabetes mellitus pada kegiatan olahraga jalan santai. Penelitian ini merupakan observasional analitik dengan pendekatan cross sectional. Sample sebanyak 68 orang yang mengikuti kegiatan olahraga jalan santai di Prolanis Padimas Surakarta. Pengambilan sample dilakukan secara purposive sampling. Kegiatan jalan santai dilakukan sejauh $2 \mathrm{~km}$ dengan waktu tempuh 30 menit. Hasil uji statistik beda pemeriksaan glukosa sebelum dan sesudah kegiatan olahraga jalan santai menggunakan uji paired T test didapatkan hasil $p<0,001$ yang menunjukan bahwa hasil signifikan atau bermakna dan memiliki nilai korelasi adalah 0,963 yang menunjukan memiliki pengaruh yang sangat kuat. Penelitian ini menyimpulkan bahwa olahraga jalan santai sejauh $2 \mathrm{~km}$ selama 30 menit dapat menurunkan kadar glukosa darah secara bermakna pada pasien diabtetes mellitus.
\end{abstract}

Kata kunci: Diabetes Melitus, Olahraga Jalan Santai, Kadar Glukosa Darah

\section{ABSTRACT}

Diabetes mellitus (DM) is a chronic disease that occurs because the pancreas cannot produce enough insulin or the body cannot effectively use the insulin that produced by the pancreas. There are 4 ways to maintain blood glucose levels, namely; pharmacological therapy, nutritional therapy, diabetes self-management education, and physical activity. Walking exercise is the most often described as the modalities of physical activity to improve health. The Aim of this study is to know the effects of walking exercise on blood glucose levels in patients with diabetes mellitus. This study is an observational cross-sectional analytic approach. There are 68 peoples who participate in walking exercise in Prolanis Padimas Surakarta as a sample. The data sampling was done by purposive sampling. Walking exercise activities carried out as far as 2 kilometers and takes about 30 minutes. Results: The results of different statistical tests glucose before and after walking exercise activities way using paired T test showed $p<0.001$, which indicates that a significant or meaningful results and have a correlation value is 0.963 which is shown to have a very strong influence. This study found that walking exercise as far as $2 \mathrm{~km}$ for 30 minutes can lower blood glucose levels significantly in patients with diabetes mellitus.

Keywords: Diabetes Mellitus, Walking Exercise, Blood Glucose

\section{Pendahuluan}

Diabetes Melitus (DM) atau sering disebut sebagai penyakit kencing manis merupakan penyakit kronis yang terjadi karena pankreas tidak dapatmenghasilkan cukup insulinataukarenatubuh tidak dapat secara efektif menggunakan insulin yang dihasilkan oleh pankreas. Hiperglikemia atau meningkatnya kadar glukosa darah merupakan 
efek yang sering terjadi pada pasien DM. Kadar glukosa darah yang tidak terkontrol dari waktu ke waktu dapat menyebabkan kerusakan serius pada banyak sistem tubuh, khususnya saraf dan pembuluh darah (World Health Organization (WHO), 2013).

Pada tahun 2011 dari 110 negara yang dipilih terdapat 366 juta orang hidup dengan diabetes dan akan meningkat pesat pada tahun 2030 menjadi 559 juta orang. Prevalensi DM di Indonesia pada tahun 2011 mencapai 4,7\% dari populasi nasional dan diperkirakan akan mencapai 5,9\% dari populasi nasional pada tahun 2030. Jumlah penderita DM pada tahun 2011 diperkirakan mencapai 7,3 juta dan diperkirakan akan menjadi 11,8 juta pada tahun 2030 Kebanyakan orang dengan diabetes hidup di negara-negara berpenghasilan rendah dan menengah. Negara-negara ini juga akan melihat peningkatan terbesar selama 19 tahun ke depan (Whiting et al., 2011). Antara tahun 2010 dan 2030 akan ada peningkatan sebesar 69\% pada Negara sedang berkembang dan meningkat 20\% pada negara maju (Shaw et al., 2009).

Penatalaksanaan DM terdapat 4 cara penanganan untuk menjaga kontrol kadar gula darah. Cara menjaga kadar gula darah tersebut yaitu; terapi menggunakan obat atau farmakologi, terapi gizi dan nutrisi, edukasi cara manajemen diabetes mandiri, dan aktifitas fisik (American Diabetes Association (ADA), 2014). Aktifitas fisik merupakan elemen penting dalam mencegah dan menejemen DM tipe 2. Hal ini dikarenakan adanya perbaikan

secara akut maupun kronis dari aksi dan kepekaan sel terhadap insulin (Colberg et al., 2010).

Olahraga adalah gerakan badan untuk menguatkan dan menyehatkan tubuh (Departemen Pendidikan Nasional Republik Indonesia (Depdiknas), 2014). Jalan kaki merupakan aktifitas fisik yang sangat sederhana dan dapat dilakukan oleh semua golongan. Jalan kaki juga merupakan olahraga rekreasi yang dapat meningkatkan kebugaran karena bersifat olahraga aerobik (Hasibuan, 2010). Olahraga jalan santai disini merupakan olahraga jalan kaki santai dengan jarak 2 kilometer. Dilakukan selama 30 menit. Pengecekan kadar glukosa darah dilakukan sebelum dan sesudah dilakukan untuk mengetahui pengaruh akut dari latihan yang dilakukan (Hordern et al., 2010).

\section{Metode Penelitian}

Penelitian ini menggunakan desain penelitian analitik observational dengan pendekatan studi cross sectional untuk mempelajari adanya pengaruh olahraga jalan santai terhadap kadar glukosa darah pada pasien diabetes mellitus. Penelitian ini dilakukan di Prolanis Padimas Surakarta di Kelurahan Sriwedari Kecamatan Laweyan Kota Surakarta dengan waktu penelitian bulan Januari 2015. Populasi target adalah pasien diabetes mellitus di Prolanis di Surakarta, populasi aktual adalah pasien diabetes mellitus di Prolanis Padimas Surakarta.

Teknik pengambilan sampel dilakukan secara purposive sampling. Pengambilan dilakukan sesuai dengan pertimbangan kriteria restriktif yang dibuat pada penelitian. Kriteria inklusi yaitu pasien Diabetes mellitus di Prolanis Padimas Surakarta, mampu melakukan kegiatan jalan santai, dan bersedia mengikuti jalannya penelitian. Kriteria Eksklusi yaitu tidak selesai dalam mengikuti jalan santai, memiliki kadar glukosa darah sewaktu lebih dari $250 \mathrm{mg} / \mathrm{dl}$, menderita stres, dan sedang memiliki infeksi, penyakit, operasi. Subjek penelitian adalah pasien di Prolanis Padimas yang mengikuti kegiatan olahraga jalan santai dan sesuai dengan kriteria restriksi. Estimasi besar sampel dihitung menggunakan rumus numerik berpasangan dengan ditetapkan $\mathrm{Z} \alpha$ sebesar 5\% dan $Z \beta$ sebesar $10 \%$. Sample minimal didapatkan sebanyak 66 responden.

Pengumpulan data dilakukan dengan cara memeriksa kadar glukosa darah sebelum dan sesudah melakukan olahraga jalan santai. Data yang didapatkan kemudian dilakukan uji statistik menggunakan uji $\mathrm{T}$ berpasangan. Pengolahan uji statistik menggunakan SPSS versi 17 untuk windows 2007.

\section{Hasil}

Jumlah subjek penelitian ada 68 sampel pasien di Prolanis Padimas yang mengikuti kegiatan olahraga jalan santai dan sesuai dengan kriteria restriksi. 
Tabel 1. Deskripsi data berdasarkan Jenis Kelamin

\begin{tabular}{ccc}
\hline Jenis Kelamin & Frekuensi & Persentase \\
\hline Laki-laki & 34 & 50 \\
Perempuan & 34 & 50 \\
Total & 68 & 100 \\
\hline
\end{tabular}

Tabel 2. Deskripsi data berdasarkan penggunaan Insulin

\begin{tabular}{ccc}
\hline Menggunakan insulin & Frekuensi & Presentase \\
\hline Ya & 5 & 7,4 \\
Tidak & 63 & 92,6 \\
Total & 68 & 100 \\
\hline
\end{tabular}

Tabel 3. Deskripsi data berdasarkan Usia

\begin{tabular}{ccc}
\hline Usia & Frekuensi & Persentase \\
\hline$<40$ & 1 & 1,5 \\
$41-50$ & 16 & 23,5 \\
$51-60$ & 30 & 44,1 \\
$61-70$ & 15 & 22,1 \\
$>70$ & 6 & 8,8 \\
Total & 68 & 100 \\
\hline
\end{tabular}

Tabel 4. Deskripsi data hasil pengukuran kadar glukosa darah

\begin{tabular}{ccc}
\hline Kadar Glukosa Darah & Mean & Median \\
\hline Sebelum & 147,5 & 142,0 \\
Sesudah & 119,4 & 115,0 \\
Selisih & 28,13 & 28,50 \\
\hline
\end{tabular}

Tabel 5. Hasil Uji Statistik T berpasangan

\begin{tabular}{cccccc}
\hline & $\mathrm{n}$ & Rerata \pm s.b & $\begin{array}{c}\text { Perbedaan } \\
\text { Rerata } \\
\pm \mathrm{s} . \mathrm{b} .\end{array}$ & IK95\% & $\mathrm{p}$ \\
\hline GDS pre Jalan Santai & 68 & $147,51 \pm 27,71$ & $28,13 \pm 6,65$ & $\begin{array}{c}0,10- \\
0,09\end{array}$ & $<0,001$ \\
GDS post Jalan Santai & 68 & $119,38 \pm 26,30$ & & \\
\hline
\end{tabular}

Data yang terdistribusi normal memenuhi syarat untuk dilakukan uji $\mathrm{t}$ berpasangan. Uji $\mathrm{t}$ berpasangan didapatkan hasil $p>0,0001$ yang menunjukan bahwa hasil signifikan atau bermakna dan memiliki nilai korelasi sangat kuat yaitu $r$ 0,963 .

\section{Diskusi}

Aktivitas fisik merupakan salah satu pilar yang dalam penatalaksanaan DM untuk meningkatkan kepekaan sel terhadap insulin dalam memproses glukosa menjadi energi. Orang dewasa yang mengalami diabetes mellitus dianjurkan untuk melakukan olahraga aerobik intensitas sedang selama total 150 menit dalam seminggu (ADA, 2014). Olahraga aerobik intensitas sedang ditandai dengan nafas yang mulai cepat, masih bisa berbicara jelas ketika melakukan olahraga contohnya ketika melakukan jalan santai dan bersepeda (NHS, 2013). Jalan kaki merupakan aktivitas fisik dan juga bisa merupakan olahraga. Jalan kaki dikategorikan sebagai olahraga apabila dilakukan secara berkelanjutan selama minimal 30 menit (Hasibuan, 2010).

Olahraga jalan santai yang telah dilakukan pada penelitian menunjukan terdapat pengaruh yang bermakna yaitu dengan nilai $p<0,0001$ dari hasil uji t berpasangan yang memiliki nilai signifikan $\mathrm{p}<0,050$. Penelitian ini melibatkan sebanyak 68 responden. Penelitian lain yang telah dilakukan oleh Fauzi dan Anggorowati tahun 2013 yang melibatkan sebanyak 36 pasien DM di paguyuban diabetes mellitus Ngudi Laras Purbalingga juga menunjukan bahwa olahraga jalan kaki memiliki pengaruh yang bermakna terhadap penurunan kadar glukosa darah yaitu dengan nilai $\mathrm{p}<0,0001$ dari uji yang dilakukan.

Penelitian lain mengenai manfaat olahraga jenis aerobik terhadap kadar gula darah menunjukan adanya pengaruh yang bermakna. Penelitian dari Puji et al tahun 2007 didapatkan bahwa terdapat pengaruh senam aerobik terhadap penurunan kadar glukosa darah yang bermakna $(\mathrm{p}<0,001)$ pada pasien DM di Puskesmas Bukateja Purbalingga. Rata penurunan kadar glukosa darah yang terjadi adalah $30,14 \mathrm{mg} / \mathrm{dl}$. Penelitian dari Berawi et al

tahun 2013 didapatkan bahwa terdapat pengaruh senam aerobic terhadap penurunan kadar glukosa darah puasa yang bermakna ( $p$ 0,003) pada peserta senam aerobik di pusat kebugaran Sonia Bandar Lampung. Penelitian Ahmad et al tahun 2014 didapatkan bahwa aktifitas fisik 
intensitas sedang memberikan kadar glukosa darah yang lebih terkontrol dibandingkan dengan aktifitas fisik intensitas ringan di puskesmas Batua dan Bar-barraya Makassar.

Penelitian ini didapatkan hasil yang sama dengan penelitian-penelitian sebelumnya yang menyatakan bahwa olahraga aerobik memiliki pengaruh yang signifikan terhadap penurunan kadar glukosa darah. Penelitian ini lebih ditujukan untuk mengamati penurunan kadar glukosa darah secara akut dengan pengambilan sample dilakukan langsung pada saat sebelum dan setelah dilakukan olahraga secara tunggal. Penelitian yang dilakukan di prolanis Padimas Surakarta ini telah membuktikan bahwa olahraga jalan santai selama 30 menit dapat menurunkan kadar glukosa darah yang signifikan.

Penelitian ini dibandingkan dengan penelitian yang telah ada terdapat kelebihan dan kekurangannya. Kelebihan penelitian ini dibandingkan penelitian sebelumnya yaitu memiliki kelebihan pada jumlah sampel yang lebih banyak. Selain itu pengukuran kadar glukosa darah dapat dilakukan secara bersamaan antara responden satu dengan lain yang memiliki selisih waktu hanya beberapa menit saja. Sehingga responden lebih homogen. Kekurangan pada penelitian ini diabndingkan penelitian sebelumnya yaitu penelitian ini menggunkana metode observasional dengan pendekatan cross sectional yang hanya mengamati kegiatan olahraga jalan santai yang telah ada sehingga variabel perancu yang ada kurang dapat dikendalikan. Pengendalian variabel hanya dapat delakukan dengan pengambilan sampel dengan metode purposive sampling dengan menyisihkan responden yang tidak bisa dikendalikan dengan kriteria resktriksi. Selain itu penelititan ini hanya mengamati efek jangka pendek dari olahraga jalan santai terhadap kadar glukosa darah yaitu pemeriksaan kaar gula darah yang hanya dilakukan satu kali sesaat sebelum dan sesudah olahraga jalan santai.

\section{Kesimpulan}

Bedasarkan hasil dan pembahasan yang telah dilakukan dapat disimpulkan bahwa terdapat pengaruh penurunan kadar glukosa darah yang bermakna pada pasien diabetes mellitus sebelum dan sesudah melakukan olahraga jalan santai.
Hasil penurunan kadar gula darah yang bermakna ini didukung oleh beberapa penelitian yang menyatakan terdapat penurunan kadar gula darah ynag bermakna pada pasien DM yang melakukan olahraga aerobik.

\section{Daftar Pustaka}

Ahmad. W., Djafar. H., Indriasari. R., 2014. Gambaran Skor Kualitas Makanan, Aktifitas Dengan Kadar Gula DarahPenyakit DM Tipe 2. Available from: www.repository.unhas.ac.id (24 Januari 2015)

American Diabetes Association., 2013. Stress. Available in www.diabetes.org. (6 November 2014)

American Diabetes Association., 2014. Standards of Medical Care in Diabetes 2014. Diab Care. 37:14-62

Berawi. K.N., Fiana. D.N., Putri. A., 2014. Pengaruh Senam Aerobik Terhadap Kadar Glukosa Darah Puasa Pada Peserta Senam Aerobik di Pusat Kebugaran Sonia Bandar Lampung. Med Jour Lamp Univ. 4: 36-43

Colberg. S.R., Sigal.R.J.,Fernhall.B., Regensteiner.J.G., Blissmer. B.J., Rubin.R.R., Taber.R.C., Albright. A.L., Braun.B., 2010. Exercise and Type 2 Diabetes. Diab Care. 33:147-167

Dahlan, S. 2013. Statistik Untuk Kedokteran Dan Kesehatan Edisi ke 5. Jakarta:Salemba Medika. Hal. 61-86

Departemen Pendidikan Nasional., 2014. Kamus Besar Bahasa Indonesia tersedia di www. badanbahasa.kemdikbud.go.id. (3 Oktober 2014)

Fauzi. L., Anggorowati. L., 2013. Perbedaan Intensitas Jalan Kaki Dengan TerhadapPenurunan Kadar Glukosa Darah. J Kes Mas. 8(2):8591

Hasibuan. R., 2010. Terapi Sederhana Menekan Gejala Penyakit Degeneratif. J Il Kes. 8(2): 78-93

Hordern. M.D., Marwick. T.H., Wood. P., Cooney. L.M., Prins. J.B., Combes. J.F., 2010. Acute Response of Blood Glucose to Short-term Exercise in Patients With Type 2 Diabetes. J Sci Med Sport. 14: 238-42

National Health Service. 2013. Physical Activity Guidelines for Adults. Available in www. nhs.uk. (4 Oktober 2014)

National Health Service. 2013. The 10000 Steps Challenge. Available in www.nhs.uk. (5 Oktober 2014) 
Puji. I., Supriyatno. H., Santoso. A., 2007. Pengaruh Latihan Fisik; Senam Aerobik Terhadap Penurunan Kadar Gula Darah Pada Penderita DM Tipe 2 di Wilayah Puskesmas Bukateja Purbalingga. Media Ners. 1:89-99

Shaw. J.E., Sicree. R.A., Zimmet. P.Z., 2010. Global Estimates of The Prevalence of Diabetes for 2010 and 2030. Diab Res Clin Pract. 87: 4-14
Whiting. D.R., Guariguata. L., Weil. C., Shaw. J., 2011. IDF Diabetes Atlas:Global Prevalence of Diabetes for 2011 and 2030. Diab Res Clin Pract. 94: 311-21

World Health Organization., 2013. Diabetes. Available in www.who.int. (1 Oktober 2014) 